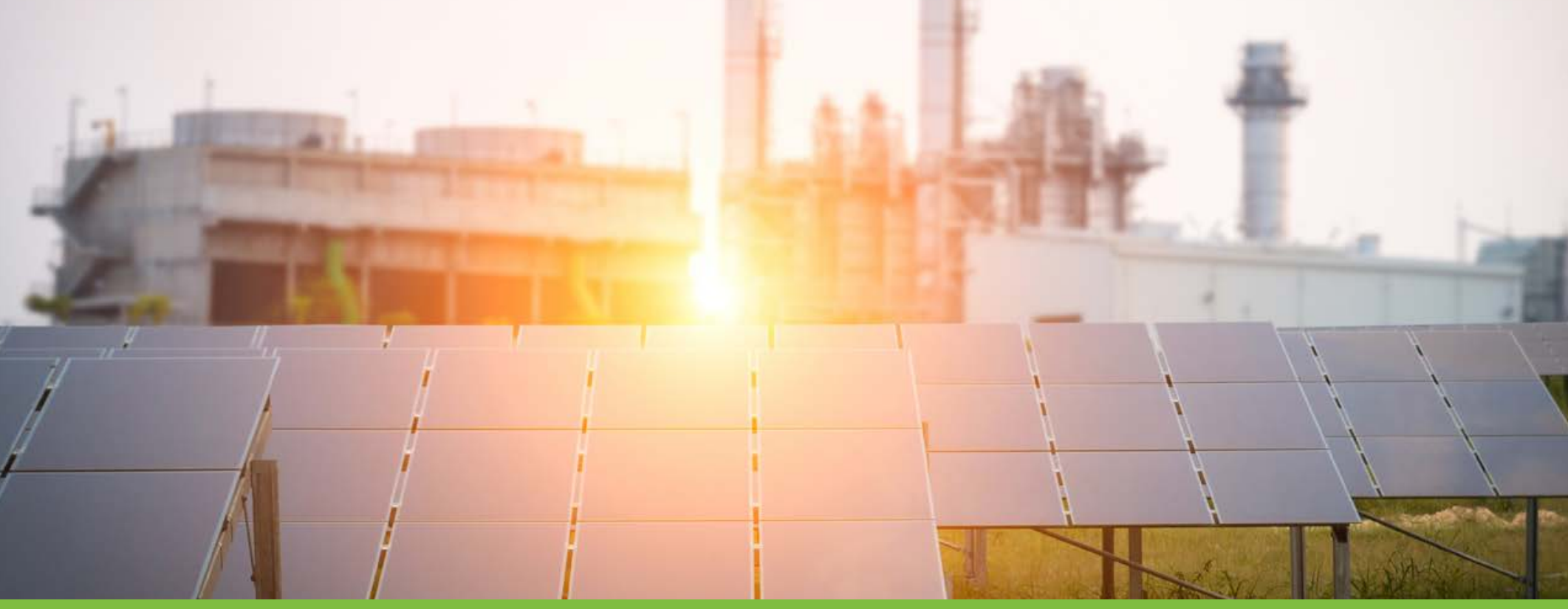

\title{
Clean Energy Integration in Natural Gas Compressor Station Operations
}

National Renewable Energy Laboratory

Emma Elgqvist, Emily Newes, Jill Engel-Cox, Ricardo Castillo

\section{Summary of Findings}

Integrating renewable energy into oil and gas operations could reduce emissions and maximize higher-value use of produced hydrocarbons. In this study, analysts from the Joint Institute for Strategic Energy Analysis (JISEA) and the National Renewable Energy Laboratory (NREL) evaluated clean power technologies for a natural gas compressor station in Texas, using NREL's REopt tool. Different configurations of distributed energy resources were evaluated based on the technologies available and the load they can satisfy, available land, and hypothetical carbon pricing. The analysis is part of a collaborative program with industry to understand site-specific energy consumption and prices in the oil and gas supply chain and determine under what conditions clean energy options are economically attractive. This work was sponsored by a consortium including Kinder Morgan, Interstate Natural Gas Association of America Foundation, Extraction Oil \& Gas, Baker Hughes, and ConocoPhillips.

\section{Snapshot}

- Smaller size renewable energy technologies can be cost-effective; larger systems (generating $50 \%$ of the site's annual load) offset significant amounts of $\mathrm{CO}_{2}$, but at an added cost.

- For grid-connected systems, the low-cost industrial electricity rates (below $\$ 0.03 /$ per kilowatt-hour) paid by these facilities frequently reduced the net present value of co-located renewable power installations beyond economic viability.

- A calculated cost of emissions reduction $\left(\$ / \mathrm{tCO}_{2} \mathrm{e}\right)$ based on renewable energy generated indicates that a carbon cost of $\$ 40 / \mathrm{tCO}_{2} \mathrm{e}$ would result in a breakeven point for a renewable energy system generating $50 \%$ of the site's load at a case study site.

- New low-carbon power technologies could represent another viable option for generating electricity on-site while decreasing emissions, although they require additional demonstration of their business models.

- Incorporating clean energy technologies and otherwise reducing the amount of fossil fuels used in the petroleum production, transportation, and refining process have the potential to both decrease energy costs and decrease greenhouse gas emissions.

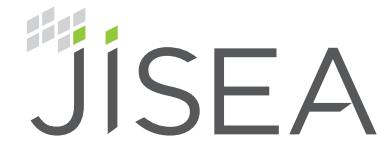

Joint Institute for Strategic Energy Analysis 
Increasing Importance

of Clean Energy in Oil \&

\section{Gas Operations}

Developing oil and gas resources remains critical to our energy and economic future in the next decade.

Prudent business practices, which are especially important in times with low oil prices, require minimizing product losses and reducing energy costs along the supply chain. Global pressure toward addressing environmental concerns and the potential advantages of clean energy-reduced impact on the environment, increased operational efficiencies, and conservation of oil and gas resources for the marketplace-are compelling the oil and gas industry to consider implementing clean technologies into their operations (Domonoske 2021). In addition, the rapid decline in the price of clean energy technologies over the past decade (Figure 1) makes them more attractive than ever before, and it is possible that the coupling of conventional generation with renewables could deliver the most feasible and economically attractive solution to decreasing emissions.
One way to meet [pre-pandemic] growing demand for oil and gas and the energy intensity required for operations-while also meeting emissions reduction goals and minimizing environmental burdens-is to integrate clean energy technologies into oil and gas operations (Ericson, Engel-Cox, and Arent 2019). Incorporating clean energy technologies and otherwise reducing the amount of fossil fuels used in petroleum production, transportation, and refining processes have the potential to decrease both energy costs and greenhouse gas emissions, as well as preserve oil and gas resources for their highest-value uses.

In 2019, JISEA established a collaborative program to:

- Support the identification, development, and adaptation of highly reliable, cost-effective clean energy solutions for oil and gas operations

- Perform techno-economic analysis and site-specific optimization of combinations of renewable and conventional generation, storage, and energy conservation

- Demonstrate the most promising technologies for validation of performance in a variety of field environments (while analyzing optimization scenarios), in partnership with industry.

Members of the consortium include Kinder Morgan, Interstate Natural Gas Association of America Foundation, Extraction Oil \& Gas, Baker Hughes, and ConocoPhillips. As part of this program, and with supporting funding from the U.S. Department of Energy, the group has explored upstream (Krah et al. 2020), midstream (Elgqvist et al. 2021), and downstream (Krah et al. forthcoming) clean energy, and energy resiliency goals. Specifically, the analysis evaluates solar photovoltaics (PV), wind turbines, and energy storage for clean energy integration into oil and gas operations. The following content describes the techno-economic modeling and results from the midstream case, focusing on compressor stations.

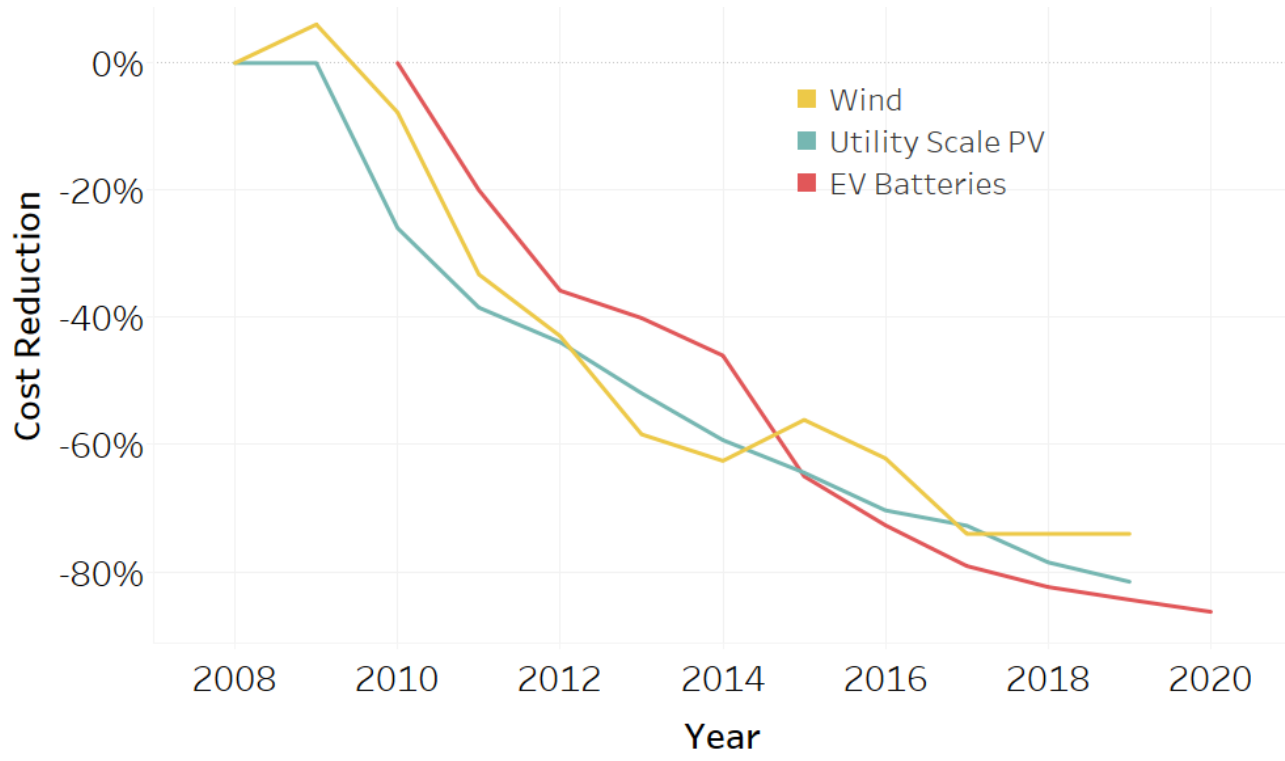

Figure 1. Clean energy technology percent cost reductions since 2008

Source: Natural Resources Defense Council 2021 


\section{Methodology}

To explore the techno-economics of renewable energy integration into oil and gas operations, JISEA/NREL analysts used NREL's techno-economic decision support model called REopt (National Renewable Energy Laboratory 2021). REopt was developed to optimize energy systems for buildings, campuses, communities, microgrids, and more. The tool recommends the optimal mix of renewable energy, conventional generation, and energy storage technologies to meet cost savings, resilience, and energy performance goals. Formulated as a mixed-integer linear program, REopt provides an integrated cost-optimal energy solution. An overview of inputs and outputs are shown in Figure 2. The technology assumptions used in REopt can be found in the Appendix.

One key input to REopt is the compressor station's electric load (typically 15-minute or hourly data), which must be met by a combination of technologies in each timestep. For this analysis, the utility costs along with distributed solar PV, wind turbines, and battery energy storage systems (BESS) were considered. The model makes decisions about the most cost-optimal combination, size (possibly zero), and dispatch of technologies based on site goals, technology costs and incentives, and utility costs that could be avoided with distributed energy technologies. REopt was also used to evaluate an additional location in the study-a gas processing facility in North Dakotawhich showed very similar results to the natural gas compressor station in Texas. Therefore only the results for the Texas site are presented in this paper.

\section{Case Study: Texas Compressor Station}

Compressor stations play an important role in transporting natural gas from the well to end users by sustaining the pressure and flow of natural gas. Compressors are built approximately every 40 to 100 miles along a pipeline. As of 2008, there were around 1,400 compressor stations in the United States. The typical unit at a compressor station is rated at least 1,000 horsepower (0.75 megawatts).
Larger stations can have up to 16 units rated at 50,000-80,000 horsepower (37-60 megawatts), moving more than 3 billion cubic feet of natural gas per day (U.S. Energy Information Administration 2008).

JISEA/NREL evaluated clean energy options for an all-electric compressor station located in Texas. The site has about 30 acres of land that could be used for solar PV or other energy development. Figure 3 shows the site's 30-minute-interval data for a full year with peaks around 20 megawatts. The load shape indicates three load levels (reflecting two units that are either on or off) and differs from a typical commercial building, highlighting the importance of using actual load data and not simulated data.

The site is classified under the large industrial power rate tariff by the electric utility for its electricity rate, with energy charges of $\$ 0.03 /$ kilowatthour. This value is low compared to commercial and residential rates, which vary from $\$ 0.05 /$ kilowatt-hour to over $\$ 0.15 /$ kilowatt-hour (Roberts 2016). The rate has a demand charge component

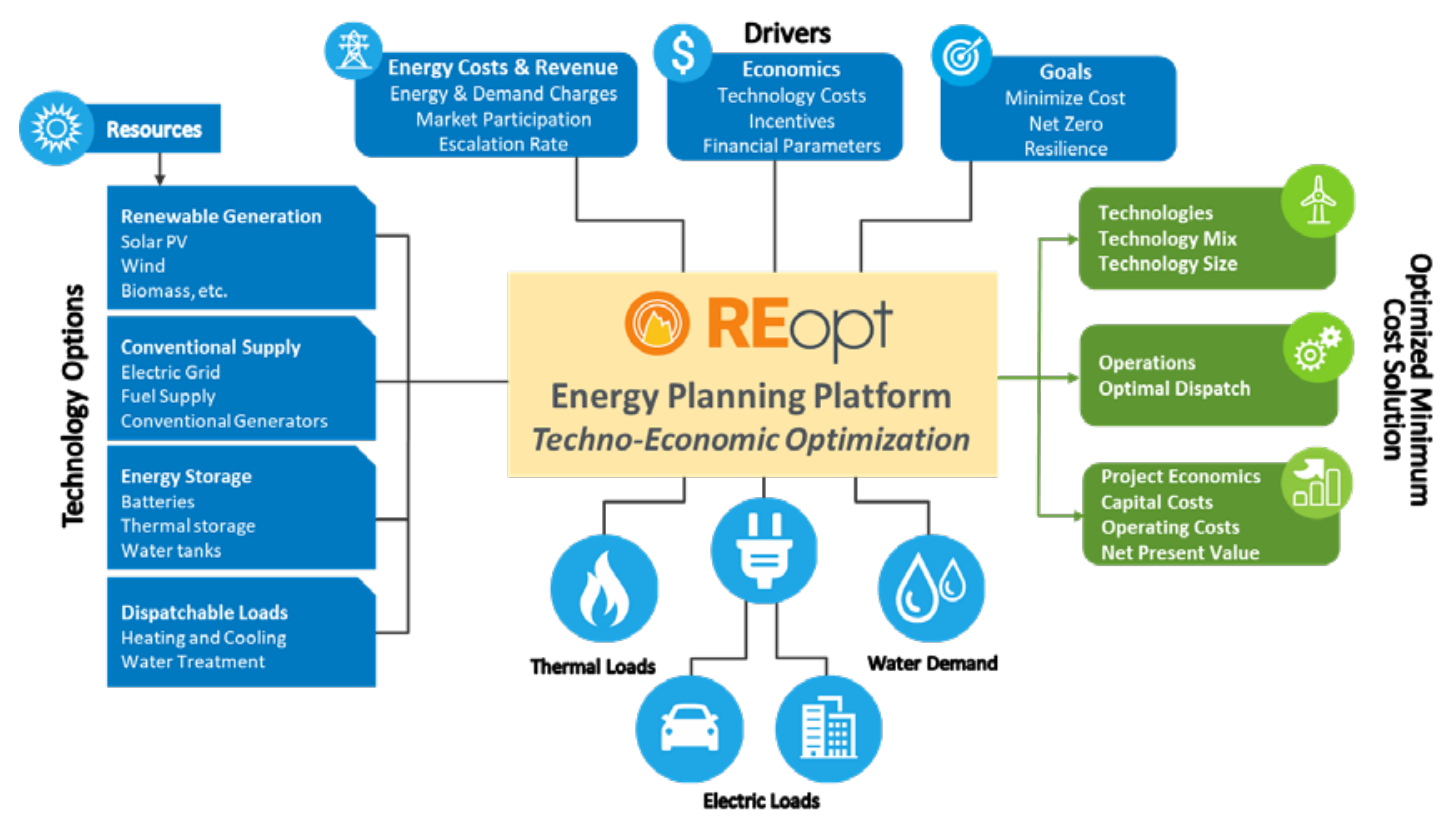

Figure 2. Overview of inputs and outputs for the REopt modeling platform 


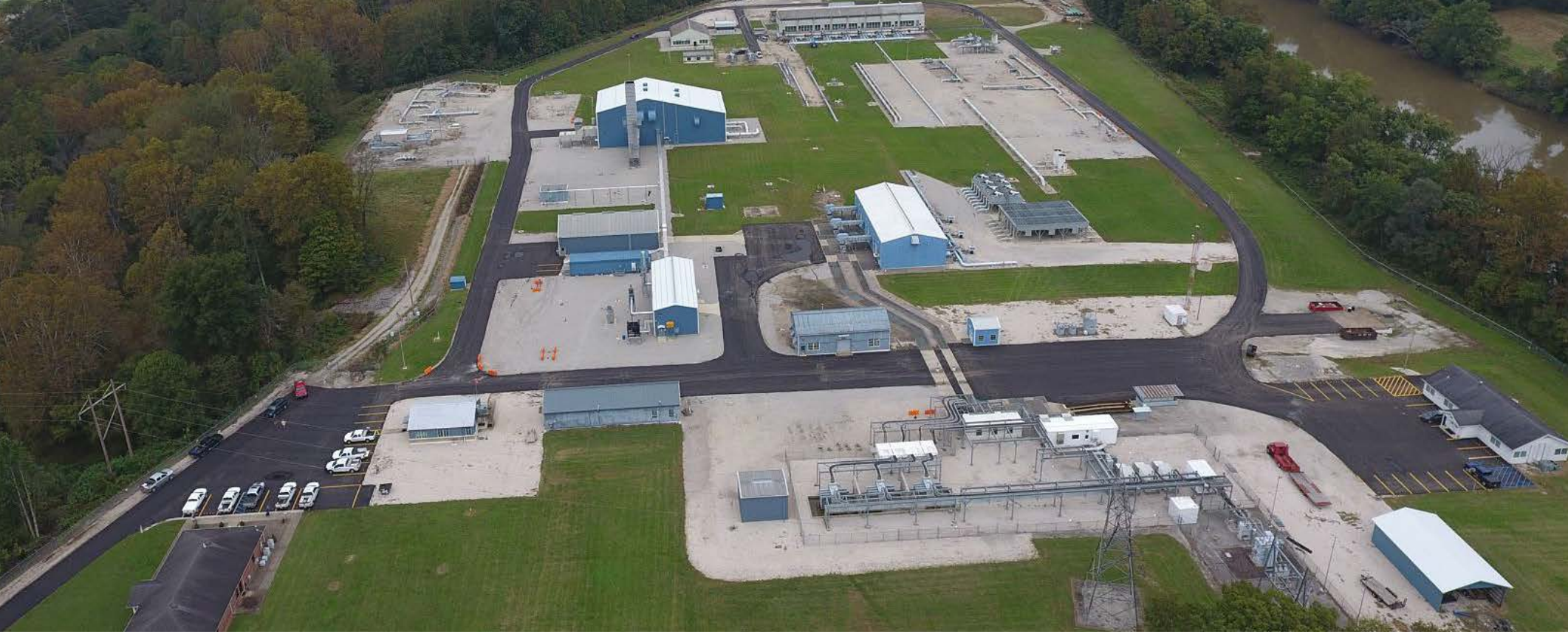

Compressor stations play an important role in transporting natural gas from the well to end users by sustaining the pressure and flow of natural gas. Note the pictured compressor station was not the one modeled in the study. Photo courtesy of Kinder Morgan

of $\$ 8 /$ kilowatt and a fixed charge (which was not included because variable renewable energy generation technologies would not offset this charge).

JISEA/NREL studied the technoeconomic potential of PV, wind, and BESS at the Texas compressor station under the following scenarios:

1. Base case life cycle cost of electricity: assumes site continues to purchase all electricity from utility grid

2. Minimum life cycle cost: size of distributed energy systems that would provide the lowest life cycle cost of electricity

3. $50 \%$ renewable energy: size of distributed energy systems that would generate $50 \%$ renewable energy on an annual basis.
Scenarios 2 and 3 were evaluated with and without full net metering of electricity generated above the site's load and with two methodologies for accounting for emissions reduction (including all renewable electricity generated by the system, or what renewable electricity is actually consumed on site).

\section{Results: Clean Energy Options for Compressor Stations}

Results indicate that smaller size renewable energy technologies (generating $5 \%$ of the site's load) are cost-optimal (Table 1). A 196-kilowatt PV system coupled with a 360-kilowatt (roughly 2 hour) battery could be costeffective and would reduce both annual energy $(\$ 9,000)$ and demand charges $(\$ 32,000)$ by reducing grid purchases (kilowatts refer to kilowatts of direct current). The net present value (NPV) over the analysis period (25 years) is $\$ 89,000$. Larger systems (generating $50 \%$ of the site's load) offset significant amounts of $\mathrm{CO}_{2}$, but at an added cost and with a negative NPV. In scenarios 2 and 3 , the model could (but did not) select to build wind turbines driven by the installed cost and wind resource at the location.

The cost of carbon offset could be compared to a carbon tax. The values shown in scenarios 2B and 3B in Table 1 are the break-even numbers, or the cost of carbon that would result in a \$O NPV for the renewable energy
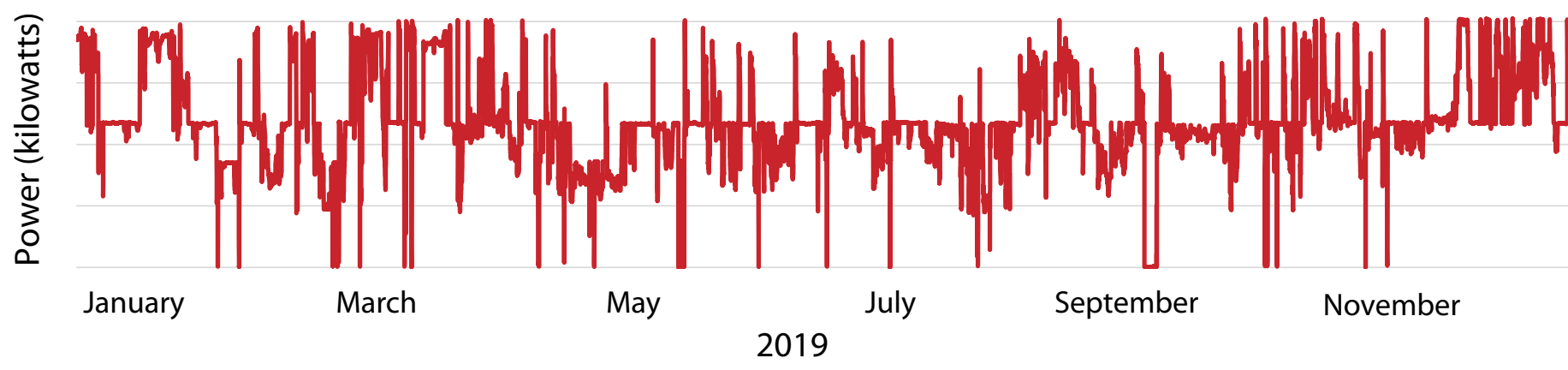

September

November

Figure 3. Thirty-minute-interval energy consumption data for a compressor station 
systems recommended, based on reduction in grid purchases. According to Greenhouse Gas Protocol (World Resources Institute and World Business Council for Sustainable Development 2021), only emission reductions from reduced grid purchases count toward emissions reduction though reduction from on-site generation can be reported as additional information. For example, if a carbon tax of \$69/ $\mathrm{tCO}_{2}$ e were enacted, it would cost the same to install the 34 megawatts of PV (with a small battery) as it would to pay the carbon tax in the scenario without net metering. If the carbon tax increased to values over $\$ 69 / \mathrm{tCO}_{2} \mathrm{e}$, it would be more cost-effective to install renewable energy technologies to provide carbon reductions. This breakeven point decreases to $\$ 38 \mathrm{tCO}_{2} \mathrm{e}$ if the site is able to fully net meter the solar PV system. The table also reports the impact of alternatively calculating these values based on total on-site renewable generation, where the break-even point without and with net metering further decrease to $\$ 49 / \mathrm{tCO}_{2} \mathrm{e}$ and $\$ 26 / \mathrm{tCO}_{2} \mathrm{e}$, respectively.

If net metering is available (scenario 3), the economics of the $50 \%$ renewable energy scenario improve significantly, because the electricity that is generated above the load is compensated at the retail value; the minimum life cycle cost solution (smaller sizes) is not impacted because the resulting electricity generation rarely, if ever, exceeds the site load. Figure 4 shows how the solar PV and battery storage system would be dispatched throughout the year. PV generated above site load could be exported to the utility or curtailed.

\section{Conclusion: Insights for Industry}

This study explored the potential for cost-effective clean energy implementation at an all-electric

Table 1. REopt Techno-Economic Results for Installation of Solar and Wind at a Kinder Morgan Compressor Station in Texas

\begin{tabular}{|c|c|c|c|c|c|}
\hline & \multicolumn{5}{|c|}{ Scenarios } \\
\hline & \multirow[t]{2}{*}{ 1. Base Case } & \multicolumn{2}{|c|}{ 2. No Net Metering } & \multicolumn{2}{|c|}{ 3. Full Net Metering } \\
\hline & & $\begin{array}{l}\text { A. Minimum Life } \\
\text { Cycle Cost }\end{array}$ & $\begin{array}{l}\text { B. } 50 \% \text { Renewable } \\
\text { Energy Generation }\end{array}$ & $\begin{array}{r}\text { A. Minimum Life } \\
\text { Cycle Cost }\end{array}$ & $\begin{array}{l}\text { B. } 50 \% \text { Renewable } \\
\text { Energy Generation }\end{array}$ \\
\hline PV size (kilowatt-DC) & - & 196 & 34,202 & 261 & 34,167 \\
\hline Battery size (kilowatt) & - & 362 & 1,020 & 378 & 386 \\
\hline Battery size (kilowatt) & - & 628 & 4,264 & 671 & 804 \\
\hline Battery size (hours) & - & 2 & 4 & 2 & 2 \\
\hline Wind size (kilowatt) & - & 0 & 0 & 0 & 0 \\
\hline Total capital cost (dollars) & $\$ 0$ & $\$ 577,780$ & $\$ 37,558,640$ & $\$ 664,635$ & $\$ 36,625,680$ \\
\hline Electricity purchases (kilowatt-hour) & $104,530,173$ & $104,232,832$ & $67,399,537$ & $104,136,003$ & $68,341,079$ \\
\hline $\begin{array}{l}\text { Percent renewable energy generated based } \\
\text { on generation (\%) }\end{array}$ & $0 \%$ & $<1 \%$ & $50 \%$ & $<1 \%$ & $50 \%$ \\
\hline Reduction in grid purchases (kilowatt-hour) & 0 & 297,355 & $37,130,650$ & 394,184 & $36,189,108$ \\
\hline $\begin{array}{l}\text { Annualized } \mathrm{CO}_{2} \mathrm{e} \text { offset based on reduction in } \\
\text { grid purchases }\left(\mathrm{tCO}_{2} \mathrm{e}\right)\end{array}$ & 0 & 116 & 14,481 & 154 & 14,114 \\
\hline $\begin{array}{l}\text { Cost of emissions reduction offset based on } \\
\text { reduction in grid purchases }\left(\$ / \mathrm{tCO}_{2} \mathrm{e}\right)\end{array}$ & - & - & $\$ 69$ & - & $\$ 38$ \\
\hline $\begin{array}{l}\text { Renewable energy generated annually } \\
\text { (kilowatt-hour) }\end{array}$ & 0 & 299,215 & $52,319,787$ & 398,860 & $52,265,601$ \\
\hline $\begin{array}{l}\text { Annualized } \mathrm{CO}_{2} \mathrm{e} \text { offset based on renewable } \\
\text { energy generated }\left(\mathrm{CCO}_{2} \mathrm{e}\right)\end{array}$ & 0 & 117 & 20,405 & 156 & 20,384 \\
\hline $\begin{array}{l}\text { Cost of emissions reduction based on } \\
\text { renewable energy generated }\left(\$ / \mathrm{tCO}_{2} \mathrm{e}\right)\end{array}$ & - & - & $\$ 49$ & - & $\$ 26$ \\
\hline Year 1 energy costs (dollars) & $\$ 3,135,905$ & $\$ 3,126,985$ & $\$ 2,021,986$ & $\$ 3,123,974$ & $\$ 1,567,967$ \\
\hline Year 1 demand costs (dollars) & $\$ 1,838,009$ & $\$ 1,805,752$ & $\$ 1,738,730$ & $\$ 1,803,505$ & $\$ 1,789,661$ \\
\hline Year 1 energy savings (dollars) & $\$ 0$ & $\$ 8,921$ & $\$ 1,113,920$ & $\$ 11,931$ & $\$ 1,567,938$ \\
\hline Year 1 demand savings (dollars) & $\$ 0$ & $\$ 32,256$ & $\$ 99,278$ & $\$ 34,503$ & $\$ 48,347$ \\
\hline Life cycle cost of electricity (dollars) & $\$ 65,634,225$ & $\$ 65,544,807$ & $\$ 78,895,025$ & $\$ 65,543,833$ & $\$ 72,718,192$ \\
\hline Net present value (dollars) & $\$ 0$ & $\$ 89,411$ & $-\$ 13,260,807$ & $\$ 90,385$ & $-\$ 7,083,973$ \\
\hline
\end{tabular}


At the request of the consortium advisory committee members, JISEA/NREL also modeled the techno-economics of an emerging technology that uses the Allam-Fetvedt Cycle, which burns natural gas with pure oxygen. The resulting high-pressure $\mathrm{CO}_{2}$ is used through the cycle and then captured, along with other industrial gas coproducts (argon and nitrogen) that are salable.

Based on information provided by the company, JISEA/NREL evaluated the economics of a 25-megawatt power plant sited behind the meter at a hypothetical compressor station and able to sell power generation on the Electric Reliability Council of Texas (ERCOT) wholesale market, valued at 2018 ERCOT west hub pricing.

Initial analysis shows potential for the technology to provide cost savings, largely driven by the value of selling gas generation (nitrogen, oxygen, argon, and $\mathrm{CO}_{2}$ ) associated with this technology (about 45\%). Additional savings come from avoided utility costs and sales to the wholesale market.

compressor station in Texas. The results indicate that smaller size renewable energy technologies are cost-effective; larger systems (generating $50 \%$ of the site's load) offset significant amounts of $\mathrm{CO}_{2}$, but at an added cost. JISEA/ NREL calculated the cost of emissions reduction $\left(\$ / \mathrm{CCO}_{2} \mathrm{e}\right)$ based on renewable energy generated and found that this too improved economics. A technology using the Allam-Fetvedt Cycle could be cost-effective for producing power and reducing emissions, but more information is needed to fully understand its market potential.

As a large energy user, a compressor station benefits from low costs of grid electricity purchases, making the economics of large-scale renewable energy integration challenging. Largescale renewable energy technology costs continue to decrease across the country. Although there is variability in renewable energy resources across the United States, it is likely that the avoided cost of electricity (coupled with current or existing policy environments) may drive prioritization and implementation of clean energy projects.

\section{References}

Domonoske, Camila. 2021. "Big Oil (Probably) Isn't Going Away Anytime Soon. But It's Definitely Changing." NPR. Org (blog). June 8, 2021. https://www. npr.org/2021/06/08/1002448099/bigoils-transition-3-takeaways-on-how-theindustry-is-and-isnt-going-green.
Ericson, Sean, Jill Engel-Cox, and Doug Arent. 2019. Approaches for Integrating Renewable Energy Technologies in Oil and Gas Operations. Golden, CO: Joint Institute for Strategic Energy Analysis. NREL/TP6A50-72842. https://www.nrel.gov/docs/ fy19osti/72842.pdf.

Krah, K., S. Ericson, X. Li, W. Olawale, R. Castillo, E. Newes, and J. Engel-Cox. Forthcoming. "Distributed Clean Energy Opportunities for Refinery Operations."

\section{--_. 2020. "Opportunities for} Clean Energy in Natural Gas Wel Operations." In 2020 IEEE International Systems Conference (SysCon), 24 August-20 September 2020, Montreal, Canada, 1-7. https://doi.org/10.1109/ SysCon47679.2020.9275853.

National Renewable Energy Laboratory. 2021. "REopt: Renewable Energy Integration \& Optimization.” https://reopt.nrel.gov/.

\section{Hourly Dispatch for 50\% RE Generation}

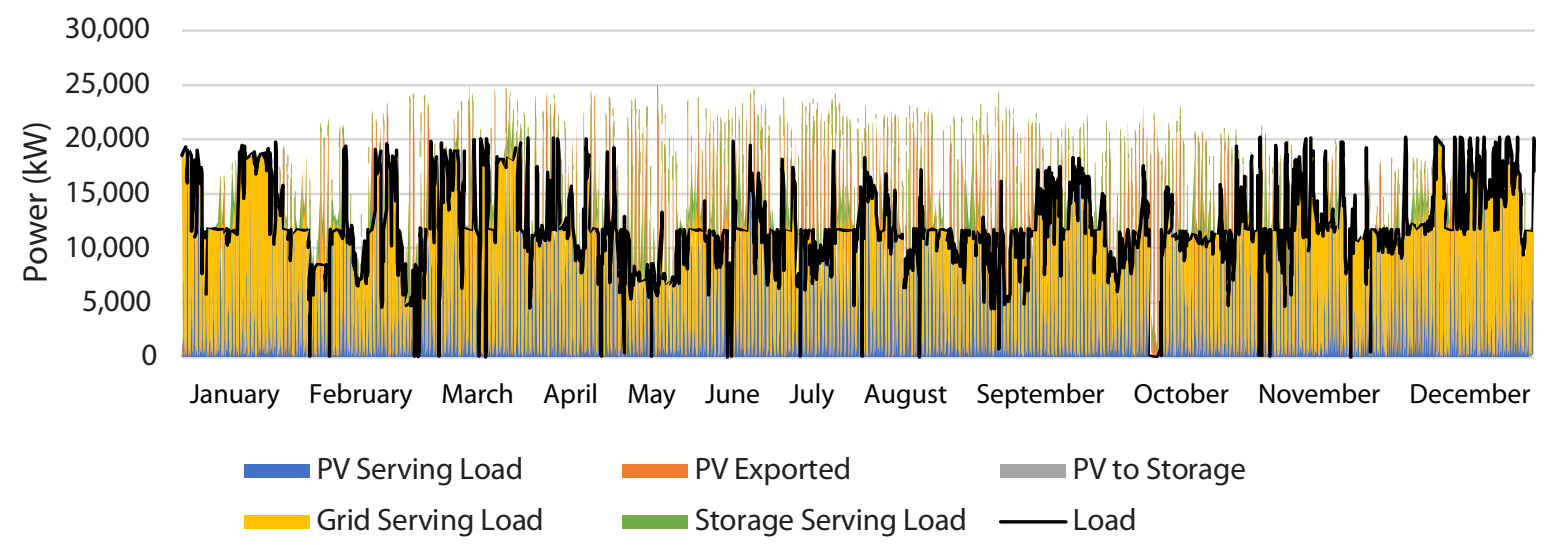

Figure 4. Hourly dispatch of solar PV and battery storage 
Natural Resources Defense Council. 2021.

"Revolution Now." https://www.nrdc.org/ revolution-now.

Roberts, Billy. 2016. "2013 Electricity Price.” OpenEl. February 26, 2016. https://openei. org/wiki/File:2013_Electricity_Price.jpg.
U.S. Energy Information Administration. 2008. "About U.S. Natural Gas Pipelines Transporting Natural Gas." https://www. eia.gov/naturalgas/archive/analysis_ publications/ngpipeline/index.html.
World Resources Institute and World Business Council for Sustainable Development. 2021. "Greenhouse GasProtocol.” https://ghgprotocol.org/.

This work was authored by the Joint Institute for Strategic Energy Analysis (JISEA), operated by Alliance for Sustainable Energy, LLC, for the U.S. Department of Energy (DOE) under Contract No. DEAC36-08G028308. Funding provided by Kinder Morgan, Interstate Natural Gas Association of America Foundation, Extraction Oil \& Gas, Baker Hughes, and ConocoPhillips. The views expressed herein do not necessarily represent the views of the DOE, the U.S. Government, or sponsors.

\section{Appendix}

\section{Economic analysis assumptions}

\section{Input}

Objective

Ownership model

Build year

Analysis period

Site's discount rate (nominal)

Electricity cost

Natural gas cost

Electricity cost escalation rate (nominal)

Natural gas cost escalation rate (nominal)

Inflation rate

a https://atb.nrel.gov/

b https://www.eia.gov/outlooks/aeo/data/browser/\#/?id=3-AEO2020\&region=1-7\&cases=ref2020\&start=2018\&end=2050\&f=A\&linecha rt=ref2020-d112119a.3-3-AEO2020.1-7\& map=ref2020-d112119a.4-3-AEO2020.1-7\&sourcekey=0 and https://www.eia.gov/consumption/ commercial/maps.php

\section{Analysis assumptions for solar PV}

\begin{tabular}{|c|c|}
\hline Input & Assumption \\
\hline System type & Ground mount, single axis tracking \\
\hline Technology resource & TMY2 weather file from National Solar Radiation Database (NSRDB) \\
\hline Tilt & 0 \\
\hline Azimuth & $180^{\circ}$ (south-facing) \\
\hline Capital costs & \$1.06/W-DC (one-axis tracking utility scale) per NREL ATB ${ }^{b}$ \\
\hline Operating and maintenance $(\mathrm{O} \& \mathrm{M})$ costs & $\$ 13 / \mathrm{kW} / \mathrm{y}$ per NREL ATB \\
\hline Incentives & $\begin{array}{l}26 \% \text { Investment Tax Credit (ITC) } ; \text {; } 5 \text {-year Modified Accelerated Cost- } \\
\text { Recovery System (MACRS) }\end{array}$ \\
\hline
\end{tabular}

\section{Assumption}

Minimize life cycle cost

Direct ownership

2020

25 years

8.3\% per NREL Annual Technology Baseline (ATB)

Entergy Large Industrial Power (per Kinder Morgan)

\$1.81/MMBtu (September 2020 per Kinder Morgan)

2.49\% per EIA (2020-2045 for west south-central region - industrial) ${ }^{\mathrm{b}}$

$3.68 \%$ per EIA (2020-2045 for west south-central region - industrial) ${ }^{\text {b }}$

$2.5 \%$ per NREL ATB 


\section{Analysis assumptions for battery storage}

\begin{tabular}{|c|c|}
\hline Input & Assumption $^{\mathrm{a}}$ \\
\hline Battery type & Lithium-ion \\
\hline DC-DC round-trip efficiency & $89.9 \%$ \\
\hline Capital costs & $\$ 420 / k W h+\$ 840 / k W$ \\
\hline Incentives & 26\% ITC; 5-year MACRS (assumes grid cannot charge BESS) \\
\hline \multicolumn{2}{|c|}{${ }^{\text {a } h t t p s: / / r e o p t . n r e l . g o v / t o o l / R E o p t \% 20 L i t e \% 20 W e b \% 20 T o o l \% 20 U s e r \% 20 M a n u a l . p d f ~}$} \\
\hline \multicolumn{2}{|c|}{ Analysis assumptions for wind } \\
\hline Input & Assumption \\
\hline Capital costs & $\begin{array}{l}\text { Large (>1,000 kW): \$3.450/W-AC per } 2018 \text { Distributed Wind Market } \\
\text { Report }^{\mathrm{b}}\end{array}$ \\
\hline O\&M costs & $\$ 40 / \mathrm{kW} / \mathrm{y}$ per NREL distributed wind cost analysis ${ }^{c}$ \\
\hline Incentives & 5 year MACRS; Production Tax Credit (PTC) expired in $2019^{f}$ \\
\hline \multicolumn{2}{|l|}{ a https://aws-dewi.ul.com/ } \\
\hline \multicolumn{2}{|c|}{ b https://www.energy.gov/sites/prod/files/2019/08/f65/2018\%20Distributed\%20Wind\%20Market\%20Report.pdf } \\
\hline \multicolumn{2}{|c|}{ chttps://www.nrel.gov/docs/fy17osti/67337.pdf } \\
\hline${ }^{f}$ http://programs.dsireusa.or & \\
\hline
\end{tabular}

\section{Analysis assumptions for emissions}

\begin{tabular}{|c|c|}
\hline Input & Assumption $^{\mathrm{a}}$ \\
\hline Region & SERC Mississippi Valley (SRMV) \\
\hline Total output emissions rate & $809.6 \mathrm{lb}$ CO e/MWh; $5.1 \%$ grid Ic \\
\hline \multicolumn{2}{|c|}{ a https://www.epa.gov/egrid/power-profiler\#/SRMV } \\
\hline \multicolumn{2}{|c|}{ b https://www.epa.gov/sites/production/files/2021-02/documents/egrid2019_summary_tables.pdf } \\
\hline \multicolumn{2}{|c|}{ Annual cost (or savings) = net present value $(\$) /$ present worth factor } \\
\hline \multicolumn{2}{|c|}{ Annual tCO e offset $=$ reduction in grid purchases $(\mathrm{MWh}){ }^{*}$ emissions factor $(\mathrm{tCO}$ e/MWh) } \\
\hline \multicolumn{2}{|c|}{ Cost of emissions reduction = annual cost $(\$) /$ annual $\mathrm{tCO}_{2} \mathrm{e}$ offset $\left(\mathrm{tCO}_{2} \mathrm{e}\right)$} \\
\hline
\end{tabular}

\section{RNREL}

\section{COLORADOSCHOOLOFMINES}

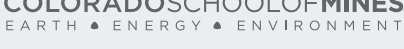

Stanford University

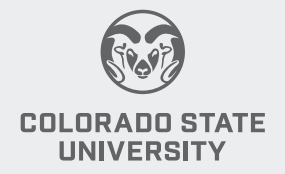

UNIVERSITY

Massachusetts Institute of Technology

(a)

JISEA is operated by the Alliance for Sustainable Energy,

LLC, on behalf of the U.S. Department of Energy's National

Renewable Energy Laboratory, the University of Colorado-

Boulder, the Colorado School of Mines, Colorado State University,

Massachusetts Institute of Technology, and Stanford University.

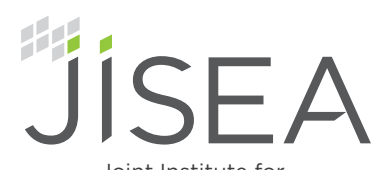

Joint Institute for Strategic Energy Analysis 